\title{
Observations on the mental health of a civilian population living under long-term hostilities
}

The civilian population of southern Lebanon has endured military conflict, civil war, and two invasions since the foundation of the State of Israel in 1948. Currently part of the south is under Israeli occupation forming a buffer zone between Israel and the hostile forces of the Hizbollah and Amal militias. The Israeli Defence Forces are aided by the South Lebanese Army which is the remnants of a Christian militia. The Hizbollah is supported by Iran and Syria and is the dominant force outside the occupation zone. In the south of Lebanon there is a United Nations mandate force which is attempting to return Lebanese government control over the south, decrease hostilities, protect the civilian population and provide humanitarian aid. This is part of the humanitarian mandate of the United Nations Interim Force in Lebanon (UNIFIL) that I had the opportunity to observe and to treat the mental health problems of the civilian population who were living under long-term artillery bombardment and living with continuous fluctuating conflict. Under such circumstances, rigorous scientific methodology in assessing the mental health of the population is extremely difficult. In order to operate effectively, as well as my own rudimentary Arabic, a translator was required. A translator does more than just translate language they also translate custom, culture and provide a valuable source of local information. Utilising my own observations and those of my valued translator, Basima, I did my best to assess how the civilian population coped with what was difficult circumstances. These assessments are value laden and I suppose are in many ways personal. My position as a military psychiatrist in the United Nations allowed me access to both the occupation zone and unoccupied Lebanon.

I noted that the medical support provided overall is patchy at best. There is a mixture of non-governmental organisations of which the international committee of the Red Cross, would appear to me to provide the most efficient service particularly in the occupation zone.

The Lebanese Army had a hospital in the village of Tibnine and the various militias run clinics from the mosques. The various units of UNIFIL provide medical support as do non-governmental organisations such as Médecins sans Frontières and Humanitarian Medical Aid and Development. There are local general practitioners some of whom trained in Europe and America. There are no trained psychiatrists in the area and the nearest psychiatric hospital is in the town of Tyre. The result of all this amalgam is a service where the continuity of care is patchy.

I observed that psychiatric illness is associated with significant stigma by the local population. While I was there, I became aware of several people being kept within their households, hidden away from the public because of psychotic illnesses. They were treated in a humane fashion, but they were a source of embarrassment to their families. With the multiplication of services, a lot of 'doctor-shopping' occurs. Patients go from one service to the next and accumulate medicines, often to quite an alarming degree. Of the psychotrophic medication, I noted that alprazolam was widely used by the civilian population.

Alprazolam is used mainly for night sedation, but also during times when the general tension of the area had significantly increased. The local population openly admits that it is the utilisation of this sedative drug which helps them get through their day to day chores. The farmers need to work, often with the sound of artillery in the distance and they can be fearful that they may come within the line of fire. The other point that I noted was the misuse of cough mixtures. Most of this is to obtain the sedative effect of bromine and diphenhydramine. Indeed in my own clinic, when I refused to dispense cough mixture it induced an adverse reaction for a short period of time. The origin of the misuse of cough mixture is interesting. Over the last two years the Hizbollah militia (which is an Islamic fundamentalist organisation) has been gaining increasing power within the area, and as a result people's behaviour has been more in keeping with Islamic law, Sharia. Those small number of establishments which sold alcohol, both to the local population and to the international forces, have been forced to close down. With their closure it would appear that cough medicine misuse increased.

I noted that a lot of stress- and anxiety-related problems were presented in a psychosomatic mode. In this situation the common term which was utilised was wajda (Arabic for pain). It was usually accompanied by the rubbing of knees. Because the population is made up of manual workers and farm workers, early osteoarthritis itself is not unusual, so a good physical workup is required. The utilisation of antidepressant medication would often have more beneficial properties than any non-steroidal anti-inflammatory drug. Because of the doctor-shopping which occurred, it was unclear what drugs people were taking and indeed, some people were on concoctions involving tricyclic antidepressants, selective serotonin re-uptake inhibitors, benzodiazepines as well as drugs for other medical conditions. I noted that the psychosomatisation of the psychological illnesses were more notable in the Israeli occupied area than in the free Lebanese area.

It must be remembered that the population being treated were the residual Lebanese Shiite population who had not fled to Tyre, Sidon and south Beirut. To a large extent these were survivors or the elderly. Indeed, it was within the Israeli controlled area that the elderly were more pronounced. On one 
occasion following the death of a patient the local population were too old to bury that patient and our help was requested.

Previously in the Lebanon, Hourani et al (1986) carried out a study of almost 6000 civilians of whom over half were displaced because of the violence of 1982. The measurements were a rough level of mental health using a symptom check-list. Their main findings included irritability and sleep disturbance. They noted a relatively low level of mental health problems and only $8 \%$ reported at least one or more items of unusual or inappropriate behaviour. In their analysis of those displaced, it was postulated that those who had been displaced suddenly, were disproportionately at risk compared with those groups who had been repeatedly displaced, that is, those who had become habituated to stress. They noticed, as I have also noticed, that the social integration of these communities is vitally important in their survival.

The level of social integration can be quite strong and indeed, I had the opportunity to observe a rather unusual occurrence in the mental health field which was reported in the international press during the summer of 1998. One man who suffers from chronic schizophrenia had left his village, on the Lebanese side and proceeded up the hill to a South Lebanese Army compound seeking to join the Army. The South Lebanese Army, realising that he was mentally ill guided him back through the wadi (valley) ensuring that he didn't fall foul of any of the minefields. Even in the midst of such trauma and killing, humanity can still be demonstrated. Watching such a population and caring for them I was impressed by their ability to maintain as normal a life as possible. As noted by Summerfield \& Toser (1991) so called 'low intensity war', frequently played out on the terrain of a subsistence economy, has high intensity consequences for its victims. Indeed, they note that a core element of modern political violence is the creation of a state of terror that penetrates the entire fabric of social relations as well as subjective mental life as a means of social control. The cohesion of the religious aspect of the population of south Lebanon cannot be underestimated. Most of this was centred around the mosques and indeed during episodes of shelling it was noted that mosques were frequently the target. The mosques provide a religious, social and a political centre for such a population.

Belonging to a mosque is almost like belonging to a family and indeed in order to communicate with the local population in a coherent fashion, it was essential to deal with them through the mosque.

Western diagnostic classifications have been noted frequently as being problematic when applied to nonWestern survivor populations. It is with regret that I did not have the company of a Lebanese psychiatrist to help me interpret the pathology that was present in this population. As noted previously, because of the conflict situation, it is an area where medical services are scant. What I did note was that many psychological complaints were presented in a somatic fashion. This I felt was an expression of a collective distress, or powerlessness in a people denied social validation of their suffering and humanity (Farias, 1991).
A Western psychiatrist would be on the lookout for symptoms of post-traumatic stress disorder (PTSD). Indeed its treatment provided many problems because of the ongoing conflict. I did note that consistent with Summerfield \& Toser (1991) hypervigilance was prevalent, but could also be life-saving. To avoid the chronic stress the population would have to become refugees. If this occurred they could lose their fields, and therefore their livelihoods and their sense of community. Overt symptoms of anxiety were occasionally demonstrated particularly among those who were active militarily within the conflict. Unfortunately, the utilisation of sedation was inappropriate because to be sedated in such an environment could leave people open to danger by reducing their response times. Attempts at psychological treatment of the symptomatology of PTSD within the civilian population was almost impossible for several reasons. One was my relatively poor ability to communicate in Arabic and I felt that I would not be able to distinguish the nuances required for psychotherapy. The other is that I was unable to remove this population from the continuous trauma within which they were living.

There are millions who remain in or near war-torn areas and we have only a base line knowledge of their mental disorders. We are inclined to look at it from a Western point of view and such a cultural perspective is often inappropriate (Skultans, 1991). I brought my own prejudices (which are Western in type) into this environment though trying desperately to view it from a more Middle-Eastern point of view. I noted that war affected people make determined efforts to preserve what they can of their culture and their way of life since this is what it means to be human (Hourani et al, 1986). As previously noted by Summerfield (1997), I would say that collective recovery over time will be fundamentally linked to the rebuilding of social and economic networks. Herein lies the source of the resilience of adults and children alike.

\section{Acknowledgements}

I would like to thank Lt Col. M. O'Dwyer and Col. Maurice Collins of the Irish Defence Forces for their help and advice.

\section{References}

FARIAS, P. (1991) Emotional distress and Transcultural Psychiatric Research socio-political correlates in Salvadoran Review, 28, 5-24 refugees: analysis of a clinical sample. Culture, Medicine and Psychiatry, 15 167-192.

HOURANI, L. L., ARMENIAN, H., ZURAYK, H., et al (1986) A populationbased survey of loss and psychological distress during war. Social Science and Medicine, 23, 269-275.

SKULTANS, V. (1991) Anthropology and psychiatry: the uneasy alliance.

SUMMERFIELD, D. (1997) The impact of war and atrocity on civilian populations. In Psychological Trauma. A Developmental Approach (eds D Black, M. Newman, J. Harris-Hendriks et al), pp.140-155. London: Gaskell.

— \& TOSER, L. (1991) Low intensity war and mental trauma: a study in a rural community. Medicine and War, 7 84-99.

John P. Tobin Consultant Psychiatrist, St Bricins Military Hospital, Infirmary Road, Dublin 7 